\title{
Scenario-based Planning of State Material Reserves: Case Study of Latvia
}

\section{Plánování státních hmotných rezerv založené na scénářích: případová studie Lotyšska}

\section{Jan Stejskal}

Abstract: The article deals with the issue of identifying required material reserves, also referred to as strategic or emergency reserves. These reserves are managed by state authority as part of national crisis preparedness. The article explores how scenarios can be used as a method for planning, i.e. determining adequate, realistic, and affordable material reserves. A scenario-based analysis, well proven in the defence planning domain, is identified as a method offering a high degree of analytical rigor and traceability of resulting requirements. Selected planning scenarios clearly must reflect national threat/hazard and risk assessments. They also have to reflect other important national policies, such as those governing economy, industry, health care, or environment. The illustrative conduct of the initial steps of the proposed method is demonstrated using Latvia's security policy circumstances.

Abstrakt: Článek se zabývá problémem stanovení požadovaných hmotných rezerv, označovaných také jako strategické nebo nouzové zásoby. Jedná se o zásoby, které obhospodařuje stát jako součást své krizové připravenosti. Článek zkoumá způsob, jak mohou být scénáře použity jako metoda pro plánování, tj. stanovení potřebných, přiměřených a ekonomicky přijatelných hmotných zásob. Analýza založená na scénářích, osvědčená v oblasti obranného plánování, je identifikována jako metoda nabízející vysokou úroveň analytické preciznosti a srozumitelnosti odůvodnění výsledných požadavků. Zvolené plánovací scénáře nepochybně musí být v souladu s národním hodnocením hrozeb a rizik. Zároveň musí zohledňovat i ostatní významné politiky státu, především v oblasti ekonomiky, průmyslu, zdravotnictví či životního prostředí. Ilustrativní provedení úvodních kroků navrhovaného metodického postupu je zasazeno do podmínek bezpečnostní politiky Lotyšské republiky.

Key words: Material Reserves; Emergency Reserves; Scenario-Based Planning; Crisis Preparedness; Hazard and Threat Assessment.

Klíčová slova: hmotné rezervy; nouzové zásoby; plánování založené na scénářích; připravenost na krize; hodnocení nebezpečí a hrozeb. 


\section{INTRODUCTION}

The early stage of the Covid-19 pandemic was, after some time, another remarkable incident which reminded national administrations of the importance of crisis preparedness. Sudden and desperate lack of certain materials and products were of grave concern. But even more importantly, the crisis revealed the individualism rooted in national policies which in similar and more severe future crises will likely govern the behaviour of states again.

Disinfectants and personal protective equipment are just the most visible and symbolic examples of materials which became scarce overnight. Why nobody thought of creating sufficient reserve of such materials in advance? What material will become scarce next time? What amount will be adequate? What should be stored in state reserve in order to be ready for the next crisis? These are the questions which usually come after the crisis. Therefore, the major challenge is to identify and raise these questions before the crisis arrives.

This article presents conclusions of a study prompted by the Latvian government's current effort to revitalize the system of state material reserves in order to be able to respond to a wide array of emergencies. The study was conducted to support the portion of work assigned to the Ministry of Defence. The main objective was to propose a systematic approach to be used to determine the required composition ("what") and the volumes ("how much") of material reserves that have to be established and maintained by the state authority. The approach should be easy to understand and provide a credible justification for the required material reserves.

\section{APPROACH}

Scenarios are widely used as a modelling tool for planning in various domains. Numerous national defence and crisis management institutions have considerable experience in using scenarios. Therefore, this article is exploiting this experience gathered mostly through NATO RTO/STO research projects. Captured experience comes mainly from the UK, Canada, Norway, Germany, the USA, the Netherlands, and in lesser extent from other countries. The first part of the article (chapters 3-6) offers general considerations and outlines the features of the planning scenarios relevant specifically for addressing the material reserves requirements. The second part (chapters 7-9) walks through the initial steps of the proposed method and identifies, as an example, the basic set of scenarios reflecting the circumstances of Latvia. 


\section{KEY TERMS AND DEFINITIONS}

To set up a common basis, the key terms appearing in this article are used in line with the following definitions.

\section{Crisis}

A crisis is understood as a situation when disturbing or disruptive factors keep affecting normal functioning of society for a certain time and with certain dynamics. Crisis is usually used to refer to a result of intentional behaviour, but it is not a constitutive characteristic of the term.

\section{Emergency/contingency}

An emergency is an extraordinary event or situation when something disturbing, disruptive and - actually or potentially - harmful happens. Such an event can happen with or without warning. The cause of an emergency can be both natural and human-made. While emergency is primarily understood as an actual event, the term contingency refers to such situations as potential or conceivable ones.

\section{Hazard}

A hazard is an accidental source (event, incident, activity) of potential disruption and harm, usually as a consequence of one or more factors and circumstances.

\section{Material reserves}

Material reserves are established as an element of a state's crisis management capacity in order to enable timely response to various emergencies which jeopardize vital and/or other important national security interests. Material reserves are designed to overcome disruption in provision of supplies or services critical to society and economy which must be re-established relatively quickly, i.e. within hours or days, while other solution simply cannot be arranged in such a short time.

Material reserves can consist of raw materials, commodities, typically fuels, semi-finished products, ready-made products and food items; modalities of their storage and protection also have to be considered as part of the overall solution.

\section{Material reserve requirement}

Material reserve requirement is the result of an analysis of a planning situation (scenario). Rusulting requirement specifies the type and amount of material or items which respond to specific features of a hazard/threat/crisis. One planning situation can generate a number of requirements.

\section{Risk}

The term risk is in general language used rather vaguely. However, in security (policy) domain, risk should not be confused with other meanings such as danger, hazard, or 
threat. ${ }^{1}$ In this study, risk is understood as an expectation of certain level of harm suffered if certain threat or danger would actually realize. ${ }^{2}$ The assessment of risk combines the severity of impact caused by an event and the likelihood of such an event happening. Risk is therefore expressed on a low-high (acceptable-unacceptable) scale. Higher levels of risk usually lead to adoption of relevant countermeasures.

\section{Scenario}

A scenario-based analysis is a tool used to structure, scope or illustrate specific tasks or activities. ${ }^{3}$ The Scenario is a model situation outlining key characteristics (such as the type, scope and scale of an emergency), and necessary sequence of events in order to depict and explore potential future reality. It has to allow understanding the impact of the emergency and the way the responsible institutions can handle it. ${ }^{4}$

\section{Threat}

A threat is a deliberate source (event, incident, activity) of potential disruption and harm. A threat is established by an actor's intention and capability to carry out respective actions to inflict harm.

\section{THE PURPOSE OF MATERIAL RESERVES AND THEIR CATEGORIES}

One of the measures to mitigate the negative impact of an emergency is to prepare in advance stockpiles of materials, equipment and consumables, a short supply of which can be arguably foreseen during the emergency.

Material reserves can be divided in few key categories according to their purpose. Establishing such categories would also reflect who, and on what basis, can authorize the use of reserves of a specific category. The typical purpose of material reserves is to

1 For brief discussion of the concept of risk, see Birkemo, Gunn Alice (2011). Is Norwegian long term defence planning risk-based? RTO-MP-SAS-093. Available at https://www.sto.nato.int/publications/ STO\%20Meeting\%20Proceedings/RTO-MP-SAS-093/MP-SAS-093-04.pdf; See also STO/NATO (2018). Analysis Support Guide for Risk-Based Strategic Planning. STO Technical Report TR-SAS-093-Part-I, March 2018. Available at https://www.sto.nato.int/publications/STO\%20Technical\%20Reports/STO-TR-SAS-093Part-I/\$\$TR-SAS-093-Part-I-ALL.pdf

2 Procházka, Josef and Melichar, Josef (2017). Methodological Framework for Operational Risk Assessment. Vojenské rozhledy. 2017, 26 (4), 18-32. DOI: 10.3849/2336-2995.26.2017.04.019-034. ISSN 1210-3292 (print), 2336-2995 (on-line). Available at https://vojenskerozhledy.cz/kategorie-clanku/strategicke-rizeni/ metodologicky-ramec

3 STO/NATO (2010). Analytic Implications of the NATO Defence Planning Process. SAS-081 Specialist Team Summary Report RTO-MP-SAS-081, p. 9-5. Available at https://www.sto.nato.int/publications/STO\%20 Meeting\%20Proceedings/RTO-MP-SAS-081/MP-SAS-081-09.pdf

4 For intensive discussion of the essence of scenarios see Whitworth, I.; Hone, G.; Farmilo, A. (2007). Developing the Scenario Assessment Tool. In Improving M\&S Interoperability, Reuse and Efficiency in Support of Current and Future Forces (pp. 8-1 - 8-14). Meeting Proceedings RTO-MP-MSG-056, Paper 8. Available at https://www.sto.nato.int/publications/STO\%20Meeting\%20Proceedings/RTO-MP-MSG-056/ MP-MSG-056-08.pdf 
enable state authorities to protect economy, ensure energy and food security of a society, support disaster relief activities, and to meet specific needs of the armed forces or other security services.

The first category would include such kind of materials which are critical (vital, essential) for surviving of population and functioning of the economy. Sudden interruption of supply of these commodities would cause significant harm and damage. This category of reserves would usually be linked to vital and other essential, or strategic, security interests of a state. Typically, they are supposed to cover consumption over a longer period, possibly up to several months. These reserves are therefore referred to as strategic reserves and are meant to provide input for critical sectors of economy and production, including production of food.

The second category would include commodities and products which are immediately needed in typically larger natural or man-made disasters to accommodate basic needs of affected people. These reserves are meant to immediately augment the normal capacity of rescue services, therefore they are usually referred to as high-readiness reserves.

Other categories are also established in some countries; we can find, e.g., reserves of materials and commodities dedicated specifically for mobilization of armed forces. These reserves may include fuels, materials for production of necessary supplies (e.g. ammunition), ready-made products, transportation vehicles etc. Reserve of certain raw material is also made when a producer is contracted to deliver certain products in case of mobilization. In order to enable immediate production upon request, this producer will use this raw material reserve.

It goes without saying that individual countries determine their required material reserves in response to their specific circumstances, their threat and hazard assessments, national interests, policy objectives etc. However, there can be groups of reserves which states are obliged to maintain on other basis than purely national decision, e.g. due to membership in an international organization. Significant in this sense is the obligation imposed on the EU member states to maintain minimum stocks of crude oil and/or petroleum products. 5

\section{TYPICAL USE OF SCENARIO-BASED ANALYSIS}

In general, scenarios are mostly used as a tool to support activities addressing possible futures and uncertainty. ${ }^{6}$ As a planning tool, they are widely used in defence planning domain. NATO as an organization uses them in its NATO Defence Planning

5 Council Directive 2009/119/EC of 14 September 2009. Available at https://eur-lex.europa.eu/ legal-content/EN/ALL/?uri=celex:32009L0119

6 Young, Thomas-Durell (2021). Capabilities-Based "Confusion": Why Capabilities-Based Planning Systems Struggle, The Korean Journal of Defense Analysis, 2021, vol. 33, no. 1, pp. 99-102. 
Process (NDPP), and a number of individual countries use them in a similar way. ${ }^{7}$ Scenarios are also used to test and verify operational concepts, typically as part of war-gaming or other simulation methods.

Crisis management is another broad domain where scenarios are employed for planning, or rather modelling purposes. Crisis management also involves producing hazard and risk assessments. Many institutions and organizations conducting risk assessments for their own purposes will do so with portraying the challenges in some form of scenarios. For instance, the UN Refugee Agency (UNHCR) has its own handbook for risk assessment, which is based on scenarios. ${ }^{8}$

Out of these examples, defence planning domain seems to have a number of analogies with material reserve planning - they both need to foresee possible future emergencies, develop the most appropriate tools to manage them, and deal with significant degree of uncertainty while doing all that. Therefore, the use of scenarios in defence planning is worth exploring.

There are five constitutive steps of the NDPP: (1) establish political guidance, (2) determine requirements, (3) apportion requirements (i.e. set targets), (4) facilitate implementation and (5) review results. ${ }^{9}$

Scenarios play their role in the second step, which can be broadly described as a complex analysis aimed at identifying the type and amount of capabilities (forces) the Alliance needs to be able to carry out its core tasks and objectives. In order to define these Minimum Capability Requirements, two types of scenarios are used in the NDPP: Generic Planning Situation and specific Case Studies.

Generic Planning Situation (GPS) is the representation of a Mission Type ${ }^{10}$ in a range of environmental conditions, without specific linkage to geographical locations. It helps capture the full capability requirements both from a mission-based and a functional perspective.

GPSs ensure that the requested capabilities from nations and NATO can be traced back to a credible foundation. A limited set of GPS, but still sufficient to represent properly the relevant planning factors, such as the Level of Ambition, intensity, distance, environment, austerity, opponent capabilities etc., is used to support the capability analysis for the derivation of the required capabilities. The set of GPSs is reviewed whenever

7 For instance, Force Planning Scenario Framework Proof of Concept (1999). Operational Research Division, Directorate of Operational Research. Department of National Defence, Canada. Available at https://ntrl. ntis.gov/NTRL/dashboard/searchResults/titleDetail/AD1003524.xhtml

8 UNHCR. Emergency Handbook. Risk analysis and monitoring - refugee emergencies. Available at https:// emergency.unhcr.org/entry/35340/risk-analysis-and-monitoring-refugee-emergencies

9 NATO (2016). The NATO Defence Planning Process. PO(2016)0655 (INV).

10 For illustration, during the conduct of MCR 2012 there were 17 agreed NATO Mission Types: Collective Defence, then three Mission Types under Defence Against Terrorism, i.e. Anti-Terrorism, Consequence Management, and Counter-Terrorism, and then 13 Mission Types in Crisis Response Operations category, e.g. Peace Enforcement, Peacekeeping, Peace Building, Humanitarian Relief, Search and Rescue, or Extraction Operations. Only 10 Mission Types were selected to form scenario set to determine the MCR. This was still considered a sufficiently representative set, since a large number of (military) Key Tasks were common to a number of Mission Types. 
required, with changes duly recorded, so they can provide a kind of reference tool for all defence planning activities.

A Case Study is the specific representation of a Generic Planning Situation in the context of actual geography, environment and a representative threat, as it is necessary to support the derivation of the required capabilities. It adds realism, drives the derivation of capability requirements and matches real-world characteristics to the GPS parameters. ${ }^{\mathbf{1 1}}$

\section{MAIN BENEFITS OF SCENARIO-BASED PLANNING}

The essence and purpose of material reserves planning and defence planning are essentially identical - it is about preparing for future crises of not fully known nature, scope and scale. ${ }^{12}$ The fact that scenarios play a significant role both in a number of national and NATO defence planning processes is important because the same value they add in this domain can be exploited also for material reserve planning. ${ }^{13}$ This method offers its added value by making it possible to:

- Establish a traceable link between the policy (guidance) and the output (the requirements). It does it by placing the political principles and policy guidelines into real-world circumstances and giving them concrete dimensions;

- Decompose and analyse complex problems and situations in a systematic way. The inherent flexibility of scenario design allows planners to establish a comprehensive structure of parameters (characteristics) essential for the planning purpose and relevant for the required output;

- Provide common framework (i.e. common set of scenarios) for all stakeholders involved in the planning process and thus ensure harmonization and maximum consistency of the outputs; This aspect seems to be particularly important in cases where no single/central institution holds overall responsibility for a certain domain (such as material reserves management);

- Lend the output a good degree of credibility due to employing scenarios with real-world characteristics and based on real-world experience;

- Visualize the problem if required.

11 Definitions used in unpublished documents prepared for participants of NDPP Step 2+ Table Top Exercise organized by ACT in 2011.

12 Conway, Maree (2004). Scenario Planning: An Innovative Approach to Strategy Development. Swinburne University of Technology. Available at https://www.researchgate.net/publication/242707360

13 For general features of scenario development see Procházka, J.; Mičánek, F.; Šmondrk, J.; Melichar, J. (2016). Scénáře v procesu plánování schopností (Scenarios in Capabilities Planning Process), Vojenské rozhledy, 2016, roč. 25 (57), č.1, s. 44-60, ISSN 1210-3292 (print), ISSN 2336-2995 (on-line). Available at https://vojenskerozhledy.cz/kategorie-clanku/vystavba-ozbrojenych-sil/ scenare-v-procesu-planovani-schopnosti2 
It is mainly the comprehensible link between the policy and the planning output and the real-world characteristics what increase buy-in of the authorities who have to endorse the result of the planning process. ${ }^{14}$

On the other hand, similarly to most of the techniques supporting foresight activities, we also have to be aware of the methodological challenges inherent to the scenario-based planning. Essentially, there are two interlinked issues: Firstly, a deep understanding and knowledge of the matter under investigation is absolutely necessary. Secondly, identification of scenarios and their actual development are a time-consuming exercise which requires interpretation of data as well as creative thinking. Therefore, both the process and results are to a large degree dependent on the participants/experts - their availability, suitability, and qualification. Even though scenario development techniques often aim to offer a standardized procedure setting certain boundaries to individual biases, the element of subjectivity will always be present. ${ }^{15}$

\section{SCENARIO SELECTION - DISTILLED NATIONAL SECURITY THREAT ASSESSMENT}

The planning scenarios have to match the national security policy, i.e., they have to represent threat/hazard and risk assessments as well as strategies designed to tackle them. ${ }^{16}$ The key issue which must be managed within scenario-based method is to ensure that a sufficiently representative spectrum of contingencies with realistic parameters are analysed. ${ }^{17}$ Concurrency of two or more contingencies may be considered, however

14 STO/NATO (2010). Analytic Implications of the NATO Defence Planning Process. SAS-081 Specialist Team Summary Report RTO-MP-SAS-081, p. 9-8.

15 For a deeper insight into the background of scenarios as a foresight and planning method, including the discussion of strenghts and weaknesses of scenario-based analysis, see e.g.:Bishop, P.; Hines, A.; Collins, T. (2007). The current state of scenario development: an overview of techniques. Foresight, Vol. 9, Issue 1, pp. 5-25. Available at https://training.fws.gov/courses/alc/alc3194/ resources/publications/scenario-planning/Bishop_et_al_2007.pdf Mietzner, D. and Reger, G. (2005). Advantages and disadvantages of scenario approaches for strategic foresight. Int. J. Technology Intelligence and Planning, Vol. 1, No. 2, pp. 220-239. Available at http://citeseerx.ist.psu.edu/viewdoc/ download?doi=10.1.1.464.3984\&rep=rep1\&type=pdf Coates, Joseph F. (2000). Scenario Planning. Technological Forecasting and Social Change, Vol. 65, Issue 1, pp. 115-123. Available at https://www. researchgate.net/profile/Javier-Enrique-Medina-Vasquez/publication/41733449_Scenario_planning/ links/559b2f0408ae21086d2784ab/Scenario-planning.pdf Merwe, Louis van der (2008). Scenario-Based Strategy in Practice: A Framework. Advances in Developing Human Resources, Vol. 10, No. 2, pp. 216-239. Available at http://www.cil.net/admin/ckeditor/filemanager/userfiles/files/Scenariobased_Strategy_in_ Practice.pdf

16 Larson, Eric V. (2019). Force Planning Scenarios, 1945-2016: Their Origins and Use in Defense Strategic Planning. RAND Corporation, p. 2. Available at https://www.rand.org/pubs/research_reports/RR2173z1. html

17 Piper, John W. (2018). Risk Management Framework: Qualitative Risk Assessment through Risk Scenario Analysis. STO Report STO-MP-IST-166, pp. 7-14-7-16. Available at https://www.sto.nato.int/publications/ STO\%20Meeting\%20Proceedings/STO-MP-IST-166/MP-IST-166-07.pdf 
this should strictly comply with official threat and hazard assessments since it might enormously increase the resource requirements.

In this case study, the selection of scenarios supporting derivation of Latvia's material reserve requirements should be driven by the overarching threat assessment presented in the National Security Concept, currently the 2019 edition. ${ }^{18}$ In its chapter 2 , the Concept outlines the elementary threat landscape in the following way:

"National security of Latvia has military dimension, foreign policy dimension, and internal security dimension which are mutually linked. The military dimension is characterized by the military activities of Russia in the Baltic Region and also other security risks and threats that are hybrid in nature and are directed towards Latvia. The foreign policy dimension is characterized by the current international security environment, changes therein, and external threats. The internal security dimension is characterized by ensuring of the fundamental values laid down in the Constitution of the Republic of Latvia by the State. Internal security is based on a cohesive civil society with a common understanding of the fundamental values and a wish to see Latvia as an independent, democratic, legal State that belongs to the Western world."

The National Security Concept further elaborates this assessment and identifies seven main types of threats, ${ }^{19}$ as well as priority measures to prevent each of them. Here is the list of the main threats with those priority measures which clearly indicate the potential demand for material reserves:

- Military threat

(priority measure: Introduction of a comprehensive national defence system)

- Threat caused by foreign intelligence services

- Cyber threats

- Threat caused to internal security and constitutional system

(priority measure: Strengthening of the capacity of the civil defence and disaster management authorities)

- Threat caused to the information space of Latvia

- Threat caused to the economy of Latvia

(priority measure: Strengthening of Energy Security)

- Threat caused by international terrorism

It should be noted that the threat assessment presented in the National Security Concept 2019 does consider only man-made and intentional causes of emergencies. No natural disasters or accidental events are included.

18 National Security Concept 2019. Available at https://likumi.lv/ta/en/en/ id/309647-on-approval-of-the-national-security-concept

19 The description of the threats is actually quite specific. For instance, in the military domain, the main source of threat to national security of Latvia is identified as Russia and its aggressive security policy implemented in the Baltic Region. 
Therefore, other policy and planning documents adopted at national level should be taken into account. Among the most important ones belong the State Defence Concept ${ }^{20}$ and Latvia's Risk Assessment Summary ${ }^{21}$. These are not documents of the same level, however, together they help grasp the full spectrum of threats and hazards.

Unlike the National Security Concept, the State Defence Concept 2020 identifies climate change, natural and anthropogenic (accidental) disasters, and pandemics as relevant hazards. The example of Covid-19 and its impact on society is specifically used to underline the issue of security of supply regarding certain commodities.

The latest Latvia's Risk Assessment Summary, submitted by the Ministry of Interior in 2016, covers a wide array of natural disasters and man-made accidents, an area which National Security Concept fails to capture. The list contains fourteen hazards:

- Significant information technology security incident

- Influenza pandemic

- Storm

- Damage to electricity transmission and distribution systems

- Significant railway accident

- Significant aviation accident

- Significant maritime accident

- Significant road accident

- River pollution

- Sea pollution

- Accident at an industrial risk site

- Damage to main gas pipelines

- Floods

For instance, the risk of floods has been elaborated also separately, primarily in the National Programme for the Assessment and Management of Flood Risks 2008 $2015,{ }^{22}$ and lately in the Initial flood risk assessment report for the development of the 22. 12. 2021-2027 Flood Risk Management Plan ${ }^{23}$ from 2018. These documents have, in line with the relevant EU directive, identified flood hazards under three categories. Out

20 The State Defence Concept 2020. Available at https://www.mod.gov.lv/sites/mod/files/document/ Valsts\%20aizsardzibas\%20koncepcija_ENG_0.pdf

21 Informatīvais zinojums „Par Latvijas risku novērtēšanas kopsavilkumu” (2016). (transl.: Information Report „On Latvia's Risk Assessment Summary“) Ministry of Interior. Available at http://polsis.mk.gov.lv/ documents $/ 5470$.

22 National Programme for the Assessment and Management of Flood Risks 2008 - 2015 (Plūdu riska novērtēšanas un pārvaldības nacionālā programma 2008.-2015.gadam.), Ministry of Environmet. Available at http://polsis.mk.gov.lv/documents/2432 (in Latvian), English version available at https://vvc. gov.Iv/image/catalog/dokumenti/Assessment_and_Management_of_Flood_Risks.doc

23 Sākotnējā plūdu riska novērtējuma ziṇojums 22.12.2021.-2027. gada plūdu risku pārvaldības plānu sagatavošanai (transl.: Initial flood risk assessment report for the development of the 22.12.2021-2027 Flood Risk Management Plan). Ministry of Environmet. Available at https://www.meteo.lv/fs/CKFinderJava/ userfiles/files/Vide/Udens/Ud_apsaimn/UBA\%20plani/Sakotneja_pludu_riska_novertejuma_zinojuma_ projekts_22_12_2021-2027_Pludu_riska_pavaldibas_planu_sagatavosanai.pdf 
of these, an extreme flood with a low probability ${ }^{\mathbf{2 4}}$ is considered a scenario with highest associated risk since very densely populated areas are at stake. Consequently, implementation of measures mitigating this hazard is a priority. The other two categories of flood risks are more likely, however with lesser impact.

Latvia's Risk Assessment Summary uses the notion of a risk scenario. Each of the fourteen hazards are briefly described and depicted by a simple diagram. These scenarios consist of a description of the nature of the hazard, its key features and some examples from the past. The diagrams outline the causes and consequences of these contingencies, however in quite generic manner.

The National Civil Protection Plan 2020 (available only in Latvian - Valsts civilās aizsardzības plāns) ${ }^{25}$ also contains a summary of risk assessment; however, it differs from the one mentioned in the previous paragraph (and footnote 21). The Civil Protection Plan's risk assessment lists 35 possible disaster events. Also the assessed levels of risk are different for some of the hazards. The National Civil Protection Plan describes the nature of the 35 contingencies rather briefly and mostly without any specific parameters.

At the end, we can conclude that enough attention is paid to both natural and man-made disasters within Latvia's disaster management planning documents. There is probably also enough historical data gathered on these emergencies by national crisis/disaster management institutions. However, none of the mentioned risk assessments, despite the fact that they use some form of scenario-based approach, made any attempts to quantify the potential impact of the contingencies they address.

\subsection{Generic scenarios}

Inspired by the NDPP, the scenario set can be established in two steps. In the first step, a limited number of generic scenarios (similar to Generic Planning Situations of the NDPP) would be determined. In the second step, specific scenarios will be outlined. ${ }^{26}$

Generic scenarios should provide the basic interpretation of policy considerations and the overall threat/hazard assessment; this would result in selection of broad themes of the scenarios. The following list is offered as an illustration of such themes:

24 I. e. either an extreme event with a return period of more than 200 years, or floods caused by various specific reasons.

25 Valsts civilās aizsardzības plāns (2020). Ministru kabineta rīkojums Nr. 476, Rīgā 2020. gada 26. augustā. Available at https://likumi.lv/ta/id/317006-par-valsts-civilas-aizsardzibas-planu

26 On the role of generic and specific scenarios see also Petráš, Zdeněk (2020). Tvorba úkolových uskupení jako výsledek transformace scénárư použití ozbrojených sil do požadavků na schopnosti (Forming of Task Forces as an Outcome of Transformation of Use of Force Scenarios into Capability Requirements). Vojenské rozhledy. 2020, 29 (2), 003-019. ISSN 1210-3292 (print), 2336-2995 (on-line). Available at https://www. vojenskerozhledy.cz/kategorie-clanku/vystavba-ozbrojenych-sil/tvorba-ukolovych-uskupeni 
1) NATO collective defence operation in response to a military threat posed by Russia's activities - possible variations: larger or smaller scale; combat operation either on or outside of Latvian territory; smaller or larger presence of other NATO forces;

2) hybrid threats - targeting different centres of gravity of Latvia's security, e.g. societal cohesion, economic stability, or legitimacy of government, using methods of disinformation activities, influence operations, or cyber-attacks (including on critical infrastructure);

3) some of the major global security challenges potentially affecting Latvia, the source of which can be seen outside of Latvia's territory, e.g. mass migration, or pandemics of a highly infectious disease (like Covid-19, SARS, etc.), or terrorist attacks;

4) natural disasters and other (industrial) accidents or emergencies, particularly those which already happened in the past (but not limited to them), typically floods, wildfires, draughts, extreme temperatures, accidents resulting in disruptions of gas and oil supplies, blackouts, or significant pollution.

Not all contingencies which match national threat/hazard assessment necessarily require material-intensive solutions. In order to become a planning scenario, the contingency has to clearly indicate significantly increased consumption of certain materials, products etc. Similarly, the demand for these materials also has to have a significant degree of urgency.

\subsection{Specific scenarios}

In the second step of scenario selection, specific scenarios with concrete parameters tailored to the purpose of identifying material reserve requirements should be determined. These scenarios would be equivalent to the Case Studies of the NDPP. The following list is offered as a possible scenario set reflecting the key Latvia's security challenges. It represents the threats acknowledged by the National Security Concept 2019, amended in accordance with the State Defence Concept 2020, and enlarged by potential natural and industrial disasters in line with Latvia's Risk Assessment (by the Ministry of Interior). These scenarios should include the most demanding conceivable challenge, as well as those which are expected to occur relatively frequently. While this is an illustrative example of a scenario set, the actual one would need to be generated by relevant experts and policy makers using real-world statistics and other relevant Latvia-specific information in order to achieve an appropriate degree of realism.

- Limited military confrontation with Russia; territorial integrity challenged in border area via limited clashes and ambushes; Latvian AF mobilized to the maximum extent; very short warning prior to the outbreak of hostilities; reinforcement by NATO countries is necessary;

- Military escalation of tensions between Latvia and Russia; massive Russian military presence in air, on land and at sea; NATO reinforces Baltic region with NRF 
and some Follow-on Forces; only selected part of military reserve personnel is mobilized;

- Cyber attack causing large-scale blackouts in major cities; duration 2-3 days;

- Interruption of gas supply as a hybrid warfare tool

- Mass migration wave

- Pandemics of a new type of influenza or SARS-type of virus

- Drone terrorist attack/other accident causing contamination of drinking water reservoir

- Large scale spring floods in one/two/three major river basins

- Large scale and extended-duration draughts combined with large scale wildfires at multiple locations

Given the fact that the initially selected scenarios (prior to the exclusion of those where a material-intensive solution is not identified) should originate in and represent the overall national threat and hazard assessment, all major security-related planning areas, such as crisis preparedness, resilience and defence planning, would benefit from using the same scenarios as the common basis. As a minimum, the scenarios used in Operational Analysis - the initial step of the Armed Forces Development Plan (NBS Attistibas Plāns) revised once in four years - should certainly be examined for their relevance to the material reserve planning.

\section{SCENARIO DEVELOPMENT - DETERMINING THE KEY PARAMETERS}

A systematic and sound method is ultimately required in this step where policy guidelines have to be translated into specific solutions. Detailed scenario development requires input (knowledge and data) from various fields of expertise owned by a number of relevant authorities or institutions. The aim is to:

- define relevant aspects and realistic parameters of a contingency (scenario), i.e., to outline the possible scope and scale of the contingency and its possible development;

- realistically portray full national potential, instruments and capacities to respond to emergencies (described by scenarios);

- and finally, to assess the gap between the actually available capacity and the full requirement to manage the emergency as defined by the scenario.

Out of these three, the second point will typically require knowledge of what is the current capacity available in a normal situation (for instance, the capacity of hospitals to deal with highly contagious individuals). It will also require the understanding of whether there is any surge capacity achievable by reorganization of normally available means, and what additional capacity could be realistically generated after the system (in this example hospitals) is additionally supplied with emergency means and resources, e. g., with state material reserves. These considerations also require understanding of how 
various material supplies and flows do work in a normal situation and how they possibly could work in a crisis; this is a prerequisite for making an informed assessment on reliability of supplies during any emergency. ${ }^{27}$

After the set of specific scenarios has been established, their key features and details need to be developed. None of the STO reports provides a description of particular steps in scenario development which would be detailed enough to be used as a complete manual. However, three studies carried out in the RTO/STO context ${ }^{28}$ (Whitworth, Hone, and Farmilo 2007; Little 2006; Rother 2018) suggest rather generic scenario architectures, consisting of main components and items. Based on this kind of generic architecture, the following structure of scenario components is proposed. ${ }^{29}$ It is rather a basic skeleton which should be further refined during its actual use by subject matter experts.

\subsection{Proposed components of scenarios}

\section{Purpose}

The scenario writing starts with defining the purpose the scenario serves. It should be a concise statement of the reason why the scenario is required and the goal intended to be achieved. It should also include any known limitations affecting possible solutions.

The purpose, in this case, is to determine the types and volumes of material reserves required to successfully deal with a specific contingency that a specific country can realistically face based on its national threat/hazard assessment and related risk assessment. Purpose should include the type of mission or tasks which have to be performed.

27 For a discussion of some topical aspects of security of supply see e.g. Hägglund, Mariette (2020). Rebuilding Sweden's Crisis Preparedness: Lack of Clarity Impedes Implementation. FIIA Briefing Paper no. 283, May 2020, pp. 6-8. Available at https://www.fiia.fi/wp-content/uploads/2020/05/bp283_sweden_ crisis-preparedness.pdf

28 1) Whitworth, I.; Hone, G.; Farmilo, A. (2007). Developing the Scenario Assessment Tool. In Improving M\&S Interoperability, Reuse and Efficiency in Support of Current and Future Forces (pp. 8-1 - 8-14). Meeting Proceedings RTO-MP-MSG-056, Paper 8. Available at https://www.sto.nato.int/publications/STO\%20 Meeting\%20Proceedings/RTO-MP-MSG-056/MP-MSG-056-08.pdf 2) Little, Daniel (2006). Scenario Design. In Integration of Modelling and Simulation (pp. 7-1 - 7-8). RTO-EN-MSG-043. Available at https:// www.sto.nato.int/publications/STO\%20Educational\%20Notes/RTO-EN-MSG-043/EN-MSG-043-07.pdf 3) Rother, Martin (2018). Technical Course MSG-162 on "Guideline for Scenario Development". STO-ENMSG-162. Available at https://www.sto.nato.int/publications/STO\%20Educational\%20Notes/STO-ENMSG-162/EN-MSG-162-01.pdf

29 Similarly, see a review of possible steps and components of scenarios in Gireth, Jan (2018). Approaches to scenario development. Vojenské rozhledy, 2018, 27 (3), 15-24. ISSN 1210-3292 (print), 2336-2995 (online). Available at https://www.vojenskerozhledy.cz/kategorie-clanku/strategicke-rizeni/tvorba-scenaru 


\section{Scene}

The scene should describe the nature of the emergency (hazard, threat) that is faced. It should also define the scene in the narrow sense, i.e., the context of the scenario, namely:

- Location, Geography (specification of affected physical area, terrain)

- Climate conditions

- Inhabitants (density of urbanization, density of population)

- Duration of emergency/crisis (days, weeks, months...)

\section{Factors}

- Weather

- Other natural/environmental influences

- Time (things can get worse or better, or not change significantly)

- Human factor (rationality, limited rationality, emotions)

- Information distribution and availability (availability of internet, GSM, TV; possible influence of disinformation; ability of government to distribute messages and warning)

- Market forces and tendencies

- Legal framework and legal limitations

\section{Actors}

Actors can be distinguished

1) by type:

- States, organizations, interest groups, individuals, media, industry \& trade

2) by categories:

- National / international

- Governmental/non-governmental

- Public / private

- Friendly / hostile / neutral

\section{Impact}

Impact should be defined at least in these categories:

- People - rough number of people affected (number of casualties, injured, infected, internally displaced, without accommodation etc.);

- Infrastructure and services - extent of destroyed or critically damaged physical infrastructure, both public and private: buildings, roads, railways, bridges, ports, airports, information and communication networks, pipelines, heating, electrical grid, water reservoirs and water distribution system etc.; Emergencies will likely increase demand for the use of public services, rescue services, including health care, emergency accommodation, police, etc.;

- Transport and delivery - all kinds of transport, personnel and cargo, individual and mass can be to a certain extent limited or completely denied (with possible geographical differentiation); 
- Agricultural and industrial production - production capacity can be destroyed, temporarily paused, limited, or unaffected; differentiated by sectors and location of production;

- Resources and consumables - supplies can be limited, paused, or stopped, and thus cause lack of food, water, energy, fuels, medicaments, materials for production and other more or less specialized equipment (medical protective etc.); Emergencies will likely increase consumption of such material resources significantly above normal everyday average (consumption of society/armed forces/rescue services/other services);

- Environment - some emergencies will have smaller or bigger (even catastrophic) impact on the environment as such. This will cause further effects typically on agriculture but also on other production sectors, and consequently on the health and well-being of people.

Resulting material requirements should be, in principle, determined in accordance with quantifying the Impact parameters. Therefore, the requirements can be structured using the same or similar categories as in the Impact component. For instance, people without accommodation will require some emergency sheltering (infrastructure); injured or infected people will necessitate additional capacity of medical treatment (infrastructure) as well as, e.g. special means of transportation (services) etc.

This aspect perhaps does not need further elaboration prior to the actual development of the scenarios. The scope of material requirements will be explored once the Impact component of each scenario is fully developed.

\subsection{Timeline, graduation of crisis, and level of ambition}

For most of the scenarios, a certain sequence of events over the period of time captured within a scenario will be a factor in determining the overall requirement. The aim of the time dimension is to depict certain dynamics of a crisis. In some cases, the dynamics will be limited, and the emergency will expose its full scale from the outset. In some cases, the severity of the emergency will grow gradually. Therefore, based on the nature of the emergency, the scenario should capture several points in time responding to the gradual increases of the scale of the emergency; at least the initial state and the culmination point should be expressed. This should portray the maximum demand posed by the emergency and the speed with which this maximum demand arrives.

The level of ambition regarding the response of particular emergencies has to be defined clearly to allow practical preparations in terms of material reserves planning and acquisition. The level of ambition defines the maximum extent of the harm which the state's crisis and consequence management capacity should be prepared to handle. It should determine the maximum scope and scale of a crisis for which preparations will be made. Whatever exceeds this maximum planning size should be considered to lie beyond the limits of affordable and realistic preparations. 


\subsection{General remark on a potential larger-scale armed conflict scenario}

Scenario representing a larger armed conflict would be quite specific and would deserve significantly more elaboration than other scenarios because it combines the needs of armed forces and society in a situation when access to most of the resources will very likely be strictly controlled, or limited, or denied due to hostilities. It represents a situation when the whole national economy has to be organized differently. Armed forces will first and foremost consume large volumes of ammunition, fuels, and other combat equipment. Armed forces will need to be fed. The scope of the requirement will also be influenced, for instance, by the extent to which mobilization of reserve personnel (including Home/National Guard type of units) will be required. Potential duration of conflict plays a key role since the assumed duration will determine the whole war-time logistics concept. It has to be determined how the war-time consumption will be met; how combat losses of major weapon systems will be accommodated; and the extent to which stockpiling of reserves will be used in this regard. There are various options available depending on assumed duration (and scale) of conflict: to keep just a regular operational reserve; to create larger (strategic) reserves for an extended period of combat operations; or assume that a running production and concurrent supplies will be possible during the crisis. These questions are part of a fundamental consideration of how long the armed forces can be sustained as a coherent structure which could still make use of resupply of major equipment at some point after suffering significant combat losses. The alternative is that the forces should count only on one set of equipment which will not be replaced after it gets lost in combat. In any case, the scenarios used in Operational Analysis supporting the Armed Forces Development Plan, or the scenarios used in National Defence Plan, should be part of the basis for identifying the overall state material reserve requirements. ${ }^{30}$

\section{CONCLUSIONS}

The idea of using scenario-based analysis has already been to some extent adopted by some Latvian authorities, primarily to produce risk assessments related to their areas of responsibility. However, certain inconsistency can be found in these assessments: they evaluate slightly different sets of contingencies, and even for the same contingencies, the level of risk is in some cases assessed differently. Certain incoherence can also be found in the top-level policy guidance which identifies national security challenges. The overarching National Security Concept focuses basically on inter-state relations and competition and does not consider the full range of challenges, especially the unintentional ones such as uncontrolled mass migration. This kind of challenges and hazards then appear in lower-level planning and implementation documents, however, without

30 The documents mentioned here are not publicly disclosed. 
the blessing of the overarching strategy. While this might be perceived as just a formal or bureaucratic issue, it is, nonetheless, an inconsistency which should be addressed.

In order to provide a solid basis for the material reserves planning, a systematic approach centered around scenario-based analysis was proposed. Its design also includes aspects aimed at harmonizing activities of a number of responsible institutions since Latvia moved to decentralized responsibility model for the material reserves management. The key features include:

1. All policy and planning documents relevant to security and crisis/disaster management have to be taken into account in order to draw the overall picture of potential emergencies.

2. Two-tier process is applied for scenario selection. First, generic scenarios are identified to capture all relevant contingencies. Second, specific scenarios are selected to describe the parameters of contingencies in detail. A generic structure of components to develop specific scenarios is proposed.

3. One common set of scenarios should be used for identification of all material reserve requirements. Ideally, it would be a subset of scenarios used for all defence and security related planning activities. This is an important aspect to ensure coordination and harmonization of the overall planning activities.

4. Detailed development of specific scenarios is an activity asking for expertise of many institutions, experts, as well as significant volumes of empirical data. It should be an inclusive process aiming at maximum level of realism when determining the values of individual parameters of the scenarios.

5. The traceability of the planning outputs (requirements) back to the policy guidance through the scenario development has to be maintained throughout the process. This, together with realism of the scenarios, is the main source of justification for the resulting material reserves requirements.

The first condition for a successful conduct of scenario-based analysis is a consistent, coherent, and sufficiently specific political guidance portraying all relevant hazards and threats.

There will be a number of stakeholders to material reserves management. The main stakeholders will typically include (in case of Latvia identified in a number of laws and other planning documents, such as the National Civil Protection Plan): Ministry of Defence, Ministry of Foreign Affairs, Ministry of Economics, Ministry of Interior (specifically the State Fire and Rescue Service), Ministry of Environmental Protection and Regional Development, Ministry of Transport, Ministry of Health, Ministry of Agriculture (and others if needed).

This article used the example of Latvia and her circumstances to depict some of the challenges of material reserves planning. However, the basic principle of proposed scenario-based method could be used elsewhere, namely in countries with no single authority responsible for crisis preparedness, including management of state material reserves. 
Author: Jan Stejskal, born in 1978. Graduated from the Faculty of Social Sciences, Charles University in Prague (2005) where he shortly worked as a researcher. In 2006-2019, he held a number of positions at the Defence Policy and Strategy Division of the MoD. In 2012-2015, he served as a defence adviser of the Permanent Delegation of the Czech Republic to NATO, responsible for defence policy and defence planning issues. In 2018, he worked as a senior expert of the NATO Strategic Communications Centre of Excellence in Riga. Since September 2019, he lives in Latvia and works in Latvian National Defence Academy, initially as a researcher of the Center for Security and Strategic Research, and currently in newly established Defence Technology and Innovation Center. Apart from the defence planning, societal resilience, and defence capability development issues, he also studies the Czechoslovak defence effort in the late 1930s.

How to cite:STEJSKAL Jan. Scenario-based Planning of State Material Reserves:

Case Study of Latvia. Vojenské rozhledy. 2021, 30 (4), 074-092. ISSN 12103292 (print), 2336-2995 (online). Available at: www.vojenskerozhledy.cz 